\title{
She knew only when the garland was put around her neck': Findings from an exploratory study on early marriage in Rajasthan
}

\author{
K.G. Santhya \\ Population Council \\ Nicole Haberland \\ Population Council \\ Ajay Kumar Singh \\ Population Council
}

Follow this and additional works at: https://knowledgecommons.popcouncil.org/departments_sbsr-pgy

Part of the Demography, Population, and Ecology Commons, Family, Life Course, and Society Commons, and the International Public Health Commons How does access to this work benefit you? Let us know!

\section{Recommended Citation}

Santhya, K.G., Nicole Haberland, and Ajay Kumar Singh. 2006. "'She knew only when the garland was put around her neck': Findings from an exploratory study on early marriage in Rajasthan." New Delhi:

Population Council. 


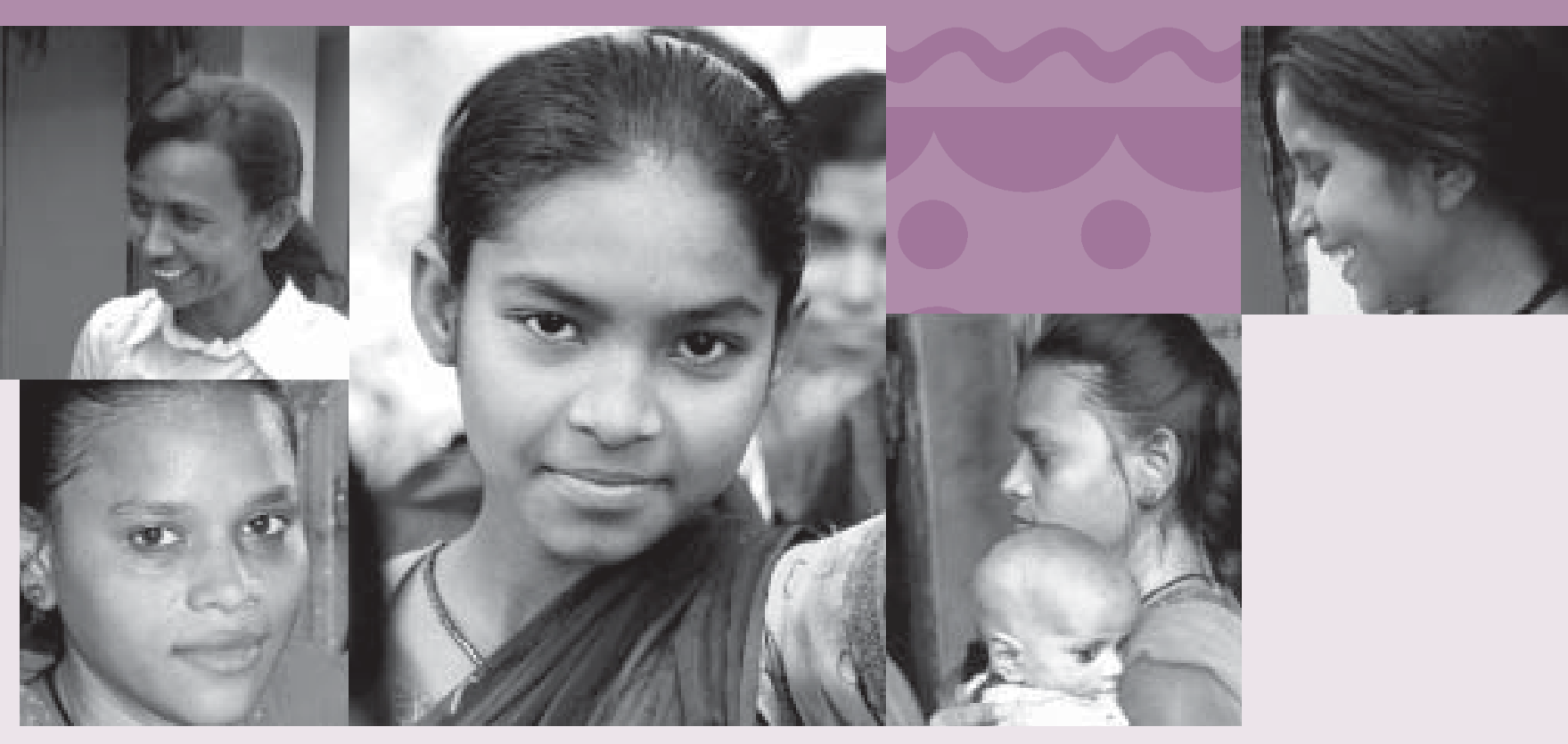

'She knew only when the garland was put around her neck':

Findings from an exploratory study on early marriage in Rajasthan 
This report is the result of an exploratory study by the Population Council to understand perceptions and realities regarding early marriage in Rajasthan.

\section{For additional copies of this report, please contact:}

\section{Population Council}

Zone 5A, Ground Floor

India Habitat Centre

Lodi Road

New Delhi 110003

Phone: 011-2464 2901/02

Email: info-india@popcouncil.org

Web site: http://www.popcouncil.org/asia/india.html

The Population Council is an international, non-profit, non-governmental organisation that seeks to improve the well-being and reproductive health of current and future generations around the world and to help achieve a humane, equitable and sustainable balance between people and resources. The Council conducts biomedical, social science and public health research, and helps build research capacities in developing countries.

Copyright @ 2006 Population Council

Suggested citation: Santhya, K.G., N. Haberland and A.K. Singh. 2006. 'She knew only when the garland was put around her neck': Findings from an exploratory study on early marriage in Rajasthan. New Delhi: Population Council 


\title{
'She knew only when the garland was put around her neck': \\ Findings from an exploratory study on early marriage in Rajasthan
}

\author{
K.G. Santhya \\ Nicole Haberland \\ Ajay Kumar Singh
}

Population Council 



\section{Contents}

Acknowledgements $\quad \mathrm{v}$

Abstract $\quad$ vi

\begin{tabular}{ll} 
Chapter 1: Introduction & 1 \\
\hline
\end{tabular}

Background 1

Study objectives $\quad 2$

Study setting 3

Methods 3

Chapter 2: Early marriage: Preferences and realities $\quad 5$

Age at marriage: Girls’ preferences $\quad 5$

Age at marriage: Parents' preferences $\quad 6$

$\begin{array}{ll}\text { Age at marriage: The reality } & 7\end{array}$

Chapter 3: Factors underlying early marriage $\quad 9$

Poverty and the burden of marriage-related expenses $\quad 9$

Concerns about finding a suitable groom

'Everyone does it': Community pressure to conform 10

Maturing bodies: Concerns about a girl's safety and family honour $\quad 10$

Limited educational opportunities for girls 11

Chapter 4: Government efforts to delay age at marriage: Perceptions and experiences 13

Campaigns to promote awareness of the legal age at marriage 13

Enforcement of the Child Marriage Restraint Act 13

$\begin{array}{ll}\text { Registration of marriage } & 15\end{array}$

$\begin{array}{ll}\text { Mass marriage ceremonies } & 15\end{array}$

Investment schemes intended to delay marriage $\quad 16$

Educational and livelihoods projects 16 
Community mobilisation through campaigns 19

Promoting education and livelihoods training for girls 21

Addressing the economic issues driving early marriage 22

$\begin{array}{ll}\text { Enforcement of the law } & 23\end{array}$

$\begin{array}{ll}\text { Addressing gender biases } & 23\end{array}$

\section{Chapter 6: Summary and conclusions: Moving beyond exhortations to clear incentives, sanctions,}

$\begin{array}{ll}\text { and community contracts } & 25\end{array}$

$\begin{array}{ll}\text { Summary } & 25\end{array}$

Increasing the pressure: Recommendations for an intensified, multi-pronged approach 26

Beyond exhortation: Critical analysis of gender and society 26

Community contracts: Fostering new norms and new practices 27

$\begin{array}{ll}\text { Meaningful consent: Respecting girls’ desires and rights } & 27\end{array}$

Economic incentives: Rewarding later age at marriage $\quad 27$

Penalties: Implementing the law $\quad 27$

Encouraging alternatives to early marriage: Education and livelihoods 28

\begin{tabular}{l} 
References \\
\hline
\end{tabular}

\begin{tabular}{ll} 
Appendix & 30 \\
\hline
\end{tabular}

Authors 


\section{Acknowledgements}

This study has benefited immeasurably from the input of many. We are enormously grateful for the support of the United Nations Foundation, the United Nations Fund for Population Assistance, the SMS Foundation and the Department for International Development (DFID) for making this study possible.

We would like to thank the adolescent girls, parents of adolescent girls, community leaders and representatives of non-governmental organisations and government departments in Alwar and Tonk who generously gave us their time and shared their views and experiences. We would also like to thank the investigators who painstakingly collected the data as well as the translators. A special thanks goes to Rajesh Singhi and colleagues at Ibtada in Alwar and Vijendra Singh and colleagues at Indian Institute of Rural Development in Tonk for their local support in data collection. We are extremely grateful to Sudhir Varma who successfully organised the data interpretation workshops and dissemination meeting. Workshop participants, including the district collectors and other representatives from the local government offices gave invaluable insights and enthusiasm.

A special thanks goes to Shireen Jejeebhoy and Saroj Pachauri for their collegial support and guidance throughout the study. Shveta Kalyanwala played a significant role at many points in the study and we appreciate her assistance immensely. We are grateful to Dinesh Agarwal and Ena Singh for reviewing an earlier draft of this report and providing helpful comments. We are grateful to Deepika Ganju for her editorial contribution and careful attention to detail. We would also like to thank Asha Matta and Komal Saxena for their help during the project. Finally, we are grateful to Vijaya Nidadavolu for overseeing the production of this report. 


\section{Abstract}

Early marriage, that is, marriage below 18 years of age, violates girls' rights, truncates their childhood and denies them a say in the choice of partner and timing of marriage. In India, despite several policy and programme efforts, early marriage persists with considerable variation between and within states. Unravelling the complex drivers of early marriage in particular contexts requires careful site-specific diagnostic research. Likewise, research is required to understand the extent of implementation of various policies and programmes intended to prevent early marriage and the extent to which such efforts have found acceptability among parents and the community. To fill this gap in existing research, the Population Council undertook an exploratory, qualitative study in two districts in Rajasthan, namely, Alwar and Tonk.

Findings show that adolescent girls had a clear desire to marry after the age of 18 and that they were well aware of what they would have to give up with marriage - their education, childhood, health and opportunities to explore other interests. Some parents also noted these disadvantages of early marriage, suggesting that beliefs may be changing though many are yet to act on these new beliefs. A range of interrelated factors, including the economic burden of marriage in a setting of high poverty, anxiety about finding a "good" spouse, pressure to abide by the societal norm, gender norms that view female sexuality as something to be controlled and gender norms that limit effective access to education for girls, appear to foster and perpetuate early marriage.

The experiences of the communities with various government programmes related to early marriage are varied and fairly superficial. Most people had witnessed campaigns against early marriage and were well aware of the fact that marriage before 18 is illegal. In contrast, most people had never heard of the government policy regarding registration of marriage. Data also show that laws, policies and programmes are implemented inconsistently. For example, respondents astutely observed that it is easy to evade legal sanctions. Moreover, the community itself appears either unconcerned or still timid; few would register a complaint if a neighbour married their young daughter. Only a few participants knew of schemes that provide positive incentives to delay age at marriage, for example the Raj Laxmi Yojana and the recently introduced Balika Samridhi Yojana, and no one was aware of anybody who had benefited from such schemes.

In order to prevent early marriage, the study participants made several suggestions for interventions that would go beyond existing information campaigns and the level of policy formulation to address fundamentally the social norms and economic factors that are driving early marriage in these districts. 
Abstract

Mobilising the community to resist early marriage through active engagement rather than passive communication efforts, promoting real access to education for girls, providing livelihoods training for girls, offering financial incentives to parents to delay the marriage of their daughters, eliminating dowry, enforcing existing laws and levying penalties for violators and fostering gender equity, were the top suggestions for action. 



\section{Introduction}

\section{Background}

In India, despite laws such as the amended Child

Marriage Restraint Act (1978) advocating 18 as the legal minimum age at marriage for females,

a substantial proportion of girls continue to marry well before the stipulated age. Indeed, as recently as 2001, one in four adolescent girls aged 15-19 was already married (RGI, 2001).

These early marriages, that is, marriages below 18 years of age, are a concern as they violate girls' rights, truncate their childhood, and frequently deny them a say in the choice of their partner and timing of marriage. Early marriage circumscribes several rights of girl children outlined in the 1989 Convention on the Rights of the Child (CRC), including the right to not be separated from their parents against their will (Article 9), the right to freedom of expression (including seeking and receiving information and ideas, Article 13), the right to education (Articles 28 and 29), the right to rest and leisure and to engage in play and recreational activities (Article 31) and the right to protection from sexual exploitation and abuse (Article 34) (UN, 1989).

Early marriage is also an issue because it interferes with the assumption of adult roles - that is, as citizens, parents and spouse/partner. As Mensch and colleagues (NRC and IOM, 2005) note, one of the preconditions for a successful transition to adulthood is the taking on of adult roles in a manner that gives young people the opportunity to acquire human and social capital, the knowledge and means to sustain health during adulthood and the capability to make choices through the acquisition of a sense of personal competence. Early marriage is unlikely to fulfil these preconditions.

Moreover, a number of social, health and economic disadvantages are associated with early marriage. While existing data do not allow conclusions regarding whether early marriage alone causes these adverse outcomes, it is likely that the links between early marriage, poverty, low educational attainment and other variables are multidirectional. Studies in diverse settings have found that married girls are likely to have frequent unprotected sexual relations. For example, analysis of Demographic and Health Survey data shows that in 27 out of 29 countries, more than half of recent reported unprotected sexual activity occurred within marriage (Bruce and Clark, 2004). Marriage dramatically increases the likelihood of and pressures for childbearing. The first-time mothers below the age 16, in addition to the normal risks and responsibilities of childbearing, face an increased risk of maternal and infant mortality (Miller and Lester, 2003). Married girls typically have low levels of educational attainment, limited or even absent peer networks, restricted mobility and less access to mass media (television, radio and newspapers) than boys or unmarried girls (Haberland, Chong and Bracken, 2004).

Efforts to delay age at marriage and to support married girls are critical, and are increasingly being emphasised by international agencies and activists. 
As a step in this direction, many governments, including the Government of India, have stipulated 18 years as the minimum age at marriage for girls. In India, the National Population Policy (2000), the National Policy for the Empowerment of Women (2001) and the National Youth Policy (2003) advocate special programmatic attention to delay age at marriage and to enforce the amended Child Marriage Restraint Act (1978). Indeed, a variety of programmes have been introduced to address the issue of early marriage. For example, the Balika Samridhi Yojana is an investment scheme with national coverage that was launched in 1997 to improve the status of the girl-child by providing girls financial incentives for completing schooling and postponing marriage till the age of $18 .^{1}$ Several state governments in India have also launched investment schemes with the specific objective of improving schooling for girls, delaying their marriage and changing family and community attitudes towards girls. Some examples are Apna Beti Apna Dhan in Haryana, ${ }^{2}$ the Girl Child Protection Scheme in Andhra Pradesh $^{3}$ and Tamil Nadu, ${ }^{4}$ Kanya Jagriti Jyoti in Punjab $^{5}$ and the Raj Laxmi Yojana ${ }^{6}$ in Rajasthan.

Little is known, however, about the extent to which these policies and programmes have been implemented at the grass-roots level in India or to what degree efforts to delay marriage have found acceptability among parents and the community (including among adolescent girls and boys). Despite declines nationally, early marriage persists in India with considerable variation between and within states. Unravelling the complex drivers of early marriage as well as gauging openness to change the practice in particular contexts requires careful site-specific diagnostic research.

To fill this significant gap in existing research, the Population Council undertook an exploratory study in two districts in Rajasthan to understand parental, community and young people's perceptions regarding early marriage, experiences with government programmes to delay girls' age at marriage, the perceived acceptability of these efforts and suggestions to eliminate the practice of early marriage.

\section{Study objectives}

The objectives of the study were to:

- Examine the perceptions of and norms surrounding early marriage and the issues underlying this practice;

\footnotetext{
${ }^{1}$ Under this scheme, the central government deposits Rs. 500 in a bank/ post office in the name of the girl child. This amount can be withdrawn to pay for an insurance policy and/or for an incremental graded scholarship to the girl-child as she graduates from different grades.

${ }^{2}$ Under this scheme, the Haryana government provides a total financial package of Rs. 3,000 to the family when a girl child is born (Rs. 500 in cash to the mother of the child within 15 days of birth and Rs. 2,500 invested in the name of the girl child for 18 years, provided she remains unmarried till then).

${ }^{3}$ This scheme provides a fixed deposit of Rs. 5,000 in the name of the girl child on the condition that she continues her studies up to the age of 18 and does not marry till then. The girl student receives Rs. 1,000 a year as a stipend from high school onwards, and Rs. 20,000 when she gets married.

${ }^{4}$ The Tamil Nadu government deposits Rs. 22,200 in the name of a girl child born into a family with only one child, provided one of the parents has undergone sterilisation The interest accrued from the deposit is used to provide a monthly stipend of a minimum of Rs. 150 throughout the period of the child's school education (Class 1- 10). The terminal benefit from the deposit with accrued interest is given to the girl after 20 years. For families with two girl-children and no male child, the government deposits Rs. 15,200 .

${ }^{5}$ For each girl child, the Punjab government invests Rs. 5,000 with Life Insurance Corporation. Previously only one girl child was eligible; however, the government recently decided to extend the benefit of the scheme to scheduled caste families with two girl children.

${ }^{6}$ Under this scheme, the Rajasthan government had deposited Rs. 1,500 in the name of the girl child with the Unit Trust of India, but the government stopped this scheme sometime back.
} 
- Explore the community's perceptions of and experiences with existing government efforts to delay age at marriage; and

- Solicit input from parents, the community and government stakeholders regarding possible programme directions for fostering later age at marriage for girls.

\section{Study setting}

The study was conducted in rural settings in the districts of Alwar and Tonk in Rajasthan, India. With 41 percent of 15-19-year-old girls and 15 percent of boys already married, the state of Rajasthan records the highest rates of early marriage among all states in India (see Appendix Table 1 for details). Inter-district disparities in the state are profound, with the rates of early marriage ranging from 24 percent of 15-19-year-old girls and 4 percent of boys in Sirohi, to 62 percent of girls and 34 percent of boys in Bhilwara (see Appendix Table 2 for details). The study districts were purposely selected to represent contrasting situations with respect to rates of early marriage Alwar representing districts with rates of early marriage similar to that of the state average and Tonk representing high prevalence districts. A few key indicators of the study districts and the state are listed in Table 1.1.

\section{Methods}

A qualitative study was conducted in four villages in Ramgarh Block in Alwar and four villages in Toda Rai Singh Block in Tonk during August-September 2005. The two blocks were purposely selected to cover villages that would provide a wide representation of religious and caste groups. Data tools included indepth interviews, focus group discussions and key informant interviews. The study participants included married and unmarried adolescent girls, parents of

Table 1.1

Profile of study districts and Rajasthan state

Characteristics
Population
Overall sex ratio*
Child (0-6 years) sex ratio*
Male literacy rate (\%)
Female literacy rate (\%)
Proportion ever married among 15-19-year-old girls
Proportion ever married among 15-19-year-old boys
Proportion of married girls aged 15-19 years who are mothers

Note: ${ }^{*}$ Sex ratio: number of females per 1,000 males Source: RGI, 2001.

\begin{tabular}{|r|r|r|}
\hline $\begin{array}{c}\text { Alwar } \\
\text { District }\end{array}$ & $\begin{array}{c}\text { Tonk } \\
\text { District }\end{array}$ & $\begin{array}{c}\text { State of } \\
\text { Rajasthan }\end{array}$ \\
\hline $2,992,592$ & $1,211,671$ & $56,507,188$ \\
886 & 934 & 921 \\
887 & 927 & 909 \\
62.9 & 70.5 & 75.7 \\
34.9 & 32.2 & 43.9 \\
42.3 & 59.2 & 40.8 \\
16.7 & 30.9 & 14.7 \\
31.3 & 16.6 & 25.1 \\
\hline
\end{tabular}


adolescent girls, influential people in the community including leaders of youth and women's groups, teachers, religious leaders and representatives of panchayats, non-governmental organisations (NGOs) and the government. A total of 16 focus group discussions, 80 in-depth interviews and 26 key informant interviews were conducted (Table 1.2).

Interviewers were locally recruited. A four-day training workshop was held to orient investigators to qualitative data collection techniques and to acquaint them with the interview guides prepared by the Council. Interviews were tape-recorded with the consent of the participants, transcribed in Hindi and translated into English. The transcripts were coded using Atlas-ti software. The preliminary findings were shared with key stakeholders in the study districts to solicit their input on data interpretation as well as on recommendations for programme and policy strategies for eliminating child marriage. Insights from the data interpretation workshops were incorporated into this final report.

Table 1.2

Study tools and respondents

\begin{tabular}{|c|c|c|c|}
\hline \multirow[t]{2}{*}{ Study tools } & \multirow[t]{2}{*}{ Type of respondent } & \multicolumn{2}{|c|}{$\begin{array}{l}\text { Number of interviews/group } \\
\text { discussions conducted }\end{array}$} \\
\hline & & Alwar & Tonk \\
\hline $\begin{array}{l}\text { Focus group } \\
\text { discussions }\end{array}$ & $\begin{array}{l}\text { Unmarried adolescent girls } \\
\text { Married adolescent girls } \\
\text { Mothers of adolescent girls } \\
\text { Fathers of adolescent girls }\end{array}$ & $\begin{array}{l}2 \\
2 \\
2 \\
2\end{array}$ & $\begin{array}{l}2 \\
2 \\
2 \\
2\end{array}$ \\
\hline $\begin{array}{l}\text { In-depth } \\
\text { interviews }\end{array}$ & $\begin{array}{l}\text { Unmarried adolescent girls } \\
\text { Married adolescent girls } \\
\text { Mothers of adolescent girls } \\
\text { Fathers of adolescent girls }\end{array}$ & $\begin{array}{l}10 \\
10 \\
10 \\
10\end{array}$ & $\begin{array}{l}10 \\
10 \\
10 \\
10\end{array}$ \\
\hline $\begin{array}{l}\text { Key informant } \\
\text { interviews }\end{array}$ & $\begin{array}{l}\text { Youth/ women's group leaders } \\
\text { Teachers } \\
\text { Religious leaders } \\
\text { Panchayat representatives } \\
\text { NGO representatives } \\
\text { Government representatives }\end{array}$ & $\begin{array}{l}2 \\
2 \\
2 \\
2 \\
1 \\
4\end{array}$ & $\begin{array}{l}2 \\
2 \\
2 \\
2 \\
1 \\
4\end{array}$ \\
\hline
\end{tabular}




\section{Early marriage: Preferences and realities}

Data from the 2001 Census clearly indicate the pervasiveness of early marriage in the state of Rajasthan as well as in many other states in India. However, little is known about girls' preferences regarding age at marriage, concerns underlying their preferences and the extent to which girls' views are considered in marriage-related decisions. This chapter discusses study findings on these issues.

\section{Age at marriage: Girls' preferences}

Most girls - married and unmarried - reported that it would be desirable to be married at 18 years or later. In Alwar, of the 20 girls interviewed, 17 said that they preferred to get married at 18-24 years and in Tonk, all except one girl said that they preferred to get married at 18 or later. A range of social, health and developmental reasons were cited for desiring to delay age at marriage. For example, girls from both sites noted that it is better to marry at ages when they are physically and mentally ready for marriage, including being prepared to responsibly take on the roles of daughter-in-law, spouse and mother. They also described the tight link between early marriage and pregnancy, and the perceived health risks associated with early childbearing.

I got married when I was very young, just 6-7 years old. I did not know anything when I got married. If I had married now, [at 17-18 years], I would have understood everything. [Married girl, Tonk] When she is mature and older than 18 , she can manage her family well and can also take care of herself. [Unmarried girl, Alwar]
[If a girl is married at 18 or 19], the children will be healthy, the mother will also be healthy, she can do all the housework, she will also make her children read and write. [Unmarried girl, Alwar]

Another set of reasons that girls gave to delay marriage was what they would lose upon early marriage, for example freedom to move about and the option to continue with their education. Having the opportunity for learning some vocational skills and thereby contributing financially to their family was also cited as reasons for preferring a later age at marriage.

If I am unmarried, I will be able to complete my studies otherwise who knows whether my in-laws will allow me to study or not. [Unmarried girl, Tonk] After marriage, I had to restrict myself to housework. I stopped going out. I felt as if I was in a jail. [Girl married at 11, Alwar]

One young woman from Tonk who was married at age 12 , noted that she would have had greater autonomy if her marriage had been later:

[It would have been better to marry] after 20, then I could have done whatever I wanted to. [Married girl, Tonk]

Regardless of whether the reasons were related to opportunities forgone, perceived adverse effects on health or not having acquired the capacity to take on the responsibilities of wife, daughter-in-law and mother, the majority of girls clearly preferred to marry at later ages than most currently do.

A comparison of girls' preferences, and girls' reports 
of their own parents' preferences, shows that roughly half of the adolescent girls - married and unmarried in both sites ( 8 out of 20 in Alwar and 12 out of 20 in Tonk) preferred to be married at a later age than desired by their parents. The consistency and clarity of girls' testimonies indicate that their desire to get married at a later age is likely very real and not merely a recitation of "propaganda" or a desire to please the interviewer.

\section{Age at marriage: Parents' preferences}

Most of the parents of unmarried girls in both Alwar and Tonk stated that their preferred age at marriage for their daughters was 18 years or older. They cited reasons similar to those mentioned by adolescent girls as to why marriage at a later age might be beneficial, including young girls not being physically or mentally mature enough for married life, not being prepared to take on household responsibilities at the marital home, perceived adverse health consequences of early pregnancy and early childbearing for the young mother and the newborn and the inability to complete studies and acquire livelihoods skills. They also noted that early marriage implies a loss of childhood for many girls and that early marriage can have an adverse effect on the marital relationship, for example, chances of marital relationship breaking up.

I prefer to get her [daughter] married at 18 or 20.

Her mind is still not developed, this is the time for her to study, to play and enjoy herself; we will not marry her now. Only then will her body have developed properly; she will become capable for her in-laws; she will be able to take care of her family and her in-laws. [Mother of unmarried girl, Tonk]

[A girl who is married early] cannot fulfil her wish of enjoying her life playfully. She has to stop her studies and do the entire housework when she goes to her sasural [in-laws]. [Mother of unmarried girl, preferring to marry her at 18-19, Alwar] Marrying children at a young age is not good. At an older age, they become more mature and understand things properly; if something happens, they will understand and hence the [marital] relationship will not break up. [Father of unmarried girl, preferring to marry her at 18-20, Tonk]

In contrast, parents who had married their daughters at a young age were, not surprisingly, somewhat reticent about the benefits of delaying marriage.

Most parents, regardless of whether they had married their daughters young or not noted that the legal age at marriage is 18 years, and that it would be a violation of the law to marry their daughters early. This is particularly true in the focus group settings where perceived "correct" and/or "socially acceptable" answers predominated. For example in a focus group discussion in Alwar with fathers of married girls, participants said that early marriage was "illegal" and "it is a crime." This is despite the fact that they themselves had married their daughters when they were children.

In general, while there is an expressed desire to delay age at marriage among parents of adolescent 
girls in both sites, parents' responses are less homogenous when compared to responses of adolescent girls and may indicate continuing support for early marriage among a substantial proportion of parents.

\section{Age at marriage: The reality}

In stark contrast to girls' articulated preferences to be married at 18 or later, and respondents' awareness of the adverse effects of early marriage, most married girls interviewed in this study were married well before age 18. In Alwar, all of the 10 married girls interviewed had been married by age 16; in fact, four were married by age 12 . Likewise, of the 10 married girls interviewed in Tonk, all except one had been married by age 16; and five were married by age 12 .

While data from married girls' and parents' interviews are not comparable since they were selected from different households, it is interesting to observe that in contrast to lower ages at marriage reported by married girls, parents of married girls reported a higher age at marriage for their daughters. In Alwar, for example, of the 10 parents of married girls interviewed, only five reported that they got their daughters married by age 16 , and the remaining five parents reported that they did not marry their daughters until they were at least age 18. Similarly of the 10 parents interviewed in Tonk, only four stated that they got their daughters married by age 16 (one of whom married off their daughter at a year-and-ahalf) while the rest reported their daughters were married by age 17 or later.

Age at cohabitation (gauna) reported by married girls in the study ranged from 14-19 years in both sites. As with age at marriage, age at cohabitation reported by parents of married adolescent girls was slightly higher (16-20 years) than that reported by married adolescent girls.

Testimonies of married girls and of parents of married girls clearly highlight that daughters' own preferences are rarely taken into account in parents' decisions regarding their marriage. In all the interviews conducted with married girls and with parents of married girls in the two sites, parents or other elders in the family decided the timing of the marriage and who the husband would be. None of the girls were asked about their preferences, nor did they have a chance to meet or talk to their future husbands.

What is there to ask them? We don't ask anyone. She knew only when the garland was put around her neck [that she was getting married]. [Mother of married girl, married at 16, Tonk]

Well, it was forced on her. She was too young to say anything. What could she say? She was a young child. What would she understand? [Mother of married girl, married at 10, Alwar]

No. No one asks like that. The girl does not meet the boy and the boy does not meet the girl. Parents decide and arrange the engagement ceremony. This is the social custom. No one can violate social norms and customs. Finding a suitable match for the child and arranging the marriage is entirely the responsibility of parents. [Father of a married girl, married at 15, Alwar]

Even in the few cases where girls expressed their views, their parents did not pay heed to them. 
[I wanted to get married at] 18. I told her [my mother] once. But she told me that I had grown up and I should marry then. [Married girl, married at 16, Alwar]

She did not want to get married, but I told her and got her married at the community centre. [Father of married girl, married at 14, Tonk]

In summary, married or not, girls were aware of the responsibilities and constraints that early marriage placed on their lives and clearly articulated a preference to marry at 18 or later ages. Many parents also expressed awareness of the adverse effects of early marriage and a preference for delayed marriages for their daughters, suggesting that beliefs may be changing in the study areas. At the same time, the findings that parents continue to control the timing of marriage, disregard their daughters' preferences in the marriage arrangement process and get their daughters married at ages earlier than desired by the girls clearly highlight that many are yet to act on these new beliefs. 


\section{Factors underlying early marriage}

The findings discussed in this chapter indicate that a variety of interrelated economic, socio-cultural and gender issues underlie the persistence of early marriage. Namely, poverty and the burden of marriage-related expenses, concerns about finding a suitable groom for one's daughter, community pressure, gender biases that limit girls' educational opportunities and norms that view girls' maturing bodies as dangerous and as signalling the need to transfer her to the perceived "safety" of marriage in order to protect her and the family's honour, emerged as key factors.

\section{Poverty and the burden of marriage-related expenses}

Poverty and the burden of marriage-related expenses were commonly reported reasons for the practice of early marriage. This emerged in focus group discussions and in-depth interviews with adolescent girls and parents in both districts, as well as with key informants. Many respondents mentioned that parents who were poor and had more than one daughter often arranged the marriage of all their daughters collectively, in one ceremony, to reduce marriage costs. This occurred even if the youngest daughter was still a child. In fact, 18 out of 40 married girls and parents of married girls interviewed reported that the marriage ceremony for all/some of their sisters/daughters in their family was held jointly.

My elder sister's marriage was fixed. So they wanted me to marry on the same day. [Married girl, Alwar, married at age 8 and gauna at 13]

\section{Concerns about finding}

\section{a suitable groom}

Another reason cited for the practice of early marriage in both sites was anxiety about finding a suitable groom. Respondents felt that the longer a family waits, the harder it is to find a "suitable boy" and a decent family for their daughter.

They [the girl's family] get both a good boy and a good family if they get their daughter married at a young age. [Married girl, Tonk]

Anxiety about finding a suitable groom also stems from a fear of what others might say about the character of the girl whose marriage is delayed, and worries about having to pay larger dowries for older girls.

Good families would not take a girl from such a family. They think that 'if the girl is old, god knows what sort of girl she is'. It becomes difficult to get her married if the girl becomes too old. [Married girl, focus group discussion, Alwar]

That is why I got them married at a young age. If I had waited longer, I would have needed more money [to pay a larger dowry]. So to save money I got them married at a young age. [Father of married girl, Alwar]

Concerns were also expressed about finding a suitable spouse for sons. Young men were said to be viewed as too old for a prospective bride if he is 20 or older, or has begun growing a beard.

The ratio of girls to boys has decreased as nowadays people get sex-determination tests done... And even 
if they have daughters, they get them married at a young age, which leads to the problem of fewer girls in society. So parents think it is better to get their sons married at a young age, otherwise if they wait too long they might not find girls for them. [Father of married girl, focus group discussion, Tonk]

Parents view it as their responsibility to find an appropriate mate - and a good family - for their daughters and sons. Marrying their children early decreases parents' anxiety and their perceived risk of finding only an unsuitable spouse, or worse yet, no spouse at all.

\section{"Everyone does it:" Community pressure to conform}

In both study sites, pressure to abide by societal norms was also cited as a reason for the persistence of early marriage. While these norms were clearly internalised by parents, neighbours and others in the community also exerted overt pressure on parents to get their daughters married at a young age.

Such pressure included enquiring from parents why they were not getting their daughters married, passing unpleasant comments about the girl and her parents or bringing them proposals for marriage.

R1: ... if they do not get their daughter married then the community and the neighbours will talk about the girl... They [parents] also think that their daughter should get married before anyone points a finger at her for remaining unmarried for a long time.

R5: People in the community start observing the girl to make sure that she does not do any thing wrong and spoil the reputation of her family.
R1: People ask why are her parents not getting her married. They say, 'She has become very old, when are they going to get her married? Are they planning to get her married when she becomes an old woman?' [Unmarried girls, focus group discussion, Tonk]

In our community, people start talking about the girl if she remains unmarried after she is 15 or 16 years old. They start saying that this girl is mature ...but her parents are still not organising her marriage. ... They also start bringing marriage proposals for the girl. [Panchayat representative, Alwar]

Some respondents noted that community pressure is so persistent that, even if a girl and her parents would like to, it would be very difficult to go against social norms and delay her age at marriage.

Everyone knows that getting married at an early age is bad. But even then everyone does it. This is a social custom. People are scared to violate this custom. Society prescribes that people go for early marriage. Ninety percent of the villagers think that early marriage is a social norm. If any one tries to violate this then he will be despised by the community. [Father of married girl, Alwar]

\section{Maturing bodies: Concerns about a girl's safety and family honour}

Girls' emerging sexuality is viewed as a threat in both sites. Fear for girls' sexual safety (e.g., fear that they will be harassed), and anxiety about girls' exploring their sexual or romantic feelings (e.g., anxiety about premarital sex and/or their daughter eloping), were 
described in both sites. Many respondents reported that such fears were not unfounded and these incidents had increased over time in their villages. Should anything so improper come to pass, the consequences would be to the girls' and her family's reputation. In part a result of these fears, but seemingly also as a factor in and of itself, puberty is viewed as a signal to promptly place a girl under the safety of the label "married". Deviating from this practice elicits community pressure - which, again, may be exerted through disparagement of a girl's reputation or her family's honour - to conform.

The following quotes demonstrate some of these perspectives. For example:

They marry their girls at a young age because there are bad people in the village. Times are not good these days. I worry even if someone touches her; her reputation will be spoilt. [Mother of unmarried girl, Alwar]

They were worried that if I didn't get married at the right age then I would do something wrong and undesirable, like falling in love and eloping with a boy. Once a girl loses her reputation, nobody will marry her. This is the worry for all parents.

[Married girl, Alwar]

[I]n rural areas, they think that till a man's daughter is married, his izzat [honour] is at stake.

[Religious leader, Alwar]

We all think only about our interests. If the girl starts looking big, we get her married irrespective of whether she is actually mature or not.

[Father of married girl, Alwar]
I got my three daughters married on the same day; at that time, the eldest was 15 years old, the second was 10 and the youngest was 7. It was very important to get them married as they were maturing. [Father of married girl, Tonk]

The fear of social sanctions for not managing girls' maturing bodies and emerging sexuality were expressed in both sites. The upshot is that the developing body of an adolescent girl is viewed as a liability or danger that can be dealt with best by pre-emptively marrying her off.

\section{Limited educational opportunities for girls}

Another critical issue reported in both study sites as underlying the persistence of early marriage was limited viable educational opportunities for girls. While many respondents observed that educated girls are more likely to delay their marriage, there were few opportunities for continuing schooling beyond Class 5 in the study villages. As educational options were limited, parents were concerned that if children did not go to school, they might go astray or get into 'trouble,' and therefore they had few options other than to get their daughters married.

Parents and their daughters are aware of the adverse socio-economic and health outcomes of early marriage. However, parents are 'helpless' in villages where there are no or limited educational facilities as they cannot keep their daughters at home, so they are getting them married.

[District level government official, Alwar]

Parents described several dimensions of the inaccessibility of education for girls. For example, 
most schools in the study villages did not offer middle or senior education. Those that did were co-educational, and parents of young girls did not consider co-education to be an option. Similarly, parents did not want to send their daughters to another village to study. A major related concern was the fear that daughters would be sexually harassed in school or on the way to school. Indeed, the perpetrators included not only adolescent boys, young men and local miscreants, but also male teachers in the schools.

They need a female teacher in that school. Boys and girls should be taught in different classes.... [I]f they study in the same room they will do wrong things.

[Mother of married girl, Tonk]

The teacher in school was not good. He would look at the girls in a 'bad' way; he would look at girls' breasts and unnecessarily shake hands with the girls. [Married girl, Alwar]

Parents also highlighted the poor quality of the schools in the study areas as a disincentive for girls' schooling. In many schools, classes were not held due to the unavailability or inadequate number of teachers. Many teachers did not have the requisite training.
They [daughters] went to school for two years but did not learn a thing. The lady teacher did not teach them properly. All she would do in the class was knitting. That is why I stopped my daughters from going to school ... it was useless and a waste of money. [Father of married girl, Alwar]

In addition to citing constraints relating to the existing educational system, participants also noted that prevailing gender norms do not value schooling for girls. Other related concerns were that parents may face difficulties in finding a "suitable boy" for their daughter if she was highly educated, or that if daughters were more educated than their husbands, the marriage might not be a success.

To sum up, the main drivers of early marriage that emerged from this study are interrelated and deeply entrenched. The economic burden of marriage in a setting of high poverty, anxiety about finding a "good" spouse for both daughters and sons, pressure to abide by the societal norm, gender norms that view female sexuality as something to be controlled and gender norms that limit effective access to education for girls appear to foster and perpetuate early marriage. 


\section{Government efforts to delay age at marriage: Perceptions and experiences}

This chapter presents findings regarding government efforts to delay age at marriage. It specifically discusses respondents' experiences with campaigns to promote awareness of the legal age at marriage; enforcement of the Child Marriage Restraint Act, 1978; registration of marriage; investment schemes, including the Balika Samridhi Yojana, intended to delay age at marriage and change family and community attitudes towards girls; and initiatives that may affect age at marriage, including educational and livelihoods programmes that can provide socially acceptable alternatives to marriage, increase girls' own capacities and self assurance and counter society's devaluation of girls.

\section{Campaigns to promote awareness of the legal age at marriage}

Study participants in both sites reported exposure to information campaigns against early marriage. School teachers and panchayat members had organised rallies in their villages, and messages were disseminated through radio and television programmes, slogans painted on buildings, billboards and other means. Participants also noted that government staff from the Department of Women and Child Development and the Department of Health and Family Welfare, such as anganwadi workers and auxiliary-nurse midwives, made home visits and counselled parents about the adverse effects of early marriage and advised them to delay marriage of their daughters at least till they were 18 years of age.

Recently (at the time of Akshay Tritiya) our panchayat received a notice from the Collector to stop child marriages. Gram sabhas [village meetings] were held in every panchayat. We organised a gram sabha and encouraged people to stop child marriages... Staff from the Department of Women and Child Development also talk about this issue when they come here. Recently they showed a film on education and child marriage. The ANM comes to the sub-centre and advises people that they should marry their children only after they are 18 years old.

[Panchayat leader, Tonk]

Consequently, most participants were aware of the legal minimum age at marriage, particularly for girls. Only four respondents in Tonk and four in Alwar reported that they did not know the legal minimum age at marriage.

\section{Enforcement of the Child Marriage Restraint Act}

Most participants were aware that violation of the Child Marriage Restraint Act, that is, marrying off a girl or boy before they have reached the legal minimum age at marriage ( 18 for girls and 21 for boys), is a punishable offence. Nonetheless, participants noted that parents of underage daughters evade punishment by secretly conducting the marriage or hiding the bride or groom when the police arrive.

Someone complained. When the police came, the elder daughter was shown as the one getting married. She too was dressed up and had henna on her hands. They are smart people. [Mother of unmarried girl, Alwar] 
The police come if they get to know that an under age boy is being married. When the police come, the family of the groom quietly puts the scarf [to indicate the groom] on an older boy, and when the police leave, they put it back on the young boy [groom]. [Unmarried girl, focus group discussion, Alwar]

Participants also observed that in practice, enforcement of the Act is weak. Those who arrange the marriage are rarely arrested, and if arrested, are soon let off. A few also mentioned that offenders bribe the police to let them conduct the marriage.

They [those who arrange early marriages] are caught. It has not happened here, but they say this on television. [Married girl, focus group discussion, Alwar]

R1: They can get punished, parents will be punished.

R6, R4: But, till now no one has been punished here. [Unmarried girls, focus group discussion, Tonk]

They were getting a young girl married in the neighbouring village. Someone complained to the police and they came and arrested them. Both the boy's and the girl's family members were arrested. The families paid money and were let off the same day. After a couple of hours they were free.

[Unmarried girl, Tonk]

An additional factor undermining enforcement is community complicity. Participants were of the view that villagers often do not report illegal marriages because they do not, in their hearts, oppose it, or, if they do register a complaint, they may be socially ostracised by the community.

The complainant is considered more guilty [than the person who arranges the early marriage]. If I complain against anyone arranging an early marriage, then I will be socially ostracised.

[Zilla Parishad member, Tonk]

Actually, no one wants to interfere in other people's affairs; they do not want to make enemies. People are not concerned about these issues in the villages.

[Father of unmarried girl, Alwar]

The mindset has not developed to stop this practice. In 2005, thousands of early marriages were conducted, but only 17 cases were reported to the police. We need to get rid of the attitude of 'hame kya lena dena' [what difference will it make to us?]. [District level police official, Tonk]

Most participants are well aware of the Child Marriage Restraint Act and the provisions for punishment if it is violated. Yet they also reported that the law has little effect. It is routinely disregarded by the community - families conduct ceremonies in secret, and few people are willing to report an illegal marriage either because they do not believe early marriage is wrong or because they fear social sanction from other community members. Moreover, even if a complaint is filed with the police and the police come to arrest the families, the families either camouflage the early marriage by pretending older siblings are getting married, or persuade or bribe the officers to avoid punishment. 


\section{Registration of marriage}

Though the National Population Policy (2000) and the Rajasthan State Population Policy (1999) have clearly articulated the need to make registration of marriages compulsory, few efforts have been made to translate these policies into action. Excerpts from interviews with panchayat leaders show that some were not aware of the government policy; and those who were aware did not make an effort to inform the community about it. Parents, too, did not approach the panchayat to register marriages.

I do not know about it [registration of marriage]. When marriages are done, they [parents] don't inform the panchayat. [Panchayat leader, Tonk]

Yes, I know about the government policy that those who get married have to get the marriage registered. We do not register marriages. They don't come here and ask us to register the marriage. The villagers don't understand at all. I don't explain. What is there to explain? [Panchayat leader, Tonk] ... the villagers do not know about it [registration of marriages]; it is not done here. [Panchayat leader, Alwar]

Findings clearly suggest that compulsory registration of marriages remains a policy prescription that is yet to be implemented. Moreover, awareness of the policy is limited even among influential people in the community such as panchayat leaders.

\section{Mass marriage ceremonies}

The government of Rajasthan has been promoting mass marriage ceremonies at the community level to reduce the burden of marriage-related expenses and to delay age at marriage. However, only a few participants in Tonk and no one in Alwar mentioned this initiative. Nonetheless, those that did know of the practice indicated that community-organised mass marriages are popular in at least some of the study villages, and that these ceremonies help parents reduce marriage-related expenses.

It is such a good system.... All the work of organising the marriage is done by the community. In such marriages, expenses are very little and everyone is given equal social status and respect. This is why people get their daughters and sons married at community marriages. [Father of unmarried girl, Tonk]

These days, common mass marriage ceremonies have started, which has given a lot of relief to parents. They have to spend just Rs. 8,000-10,000.... Both the rich and the poor have started opting for these mass marriages. The tension [of meeting marriage-related expenses] is reduced. Earlier, when the elder daughter became an adult, the younger daughter was married along with her. But these days, because there is the option of participating in a mass marriage, parents wait for their daughters to become adults before getting them married. It is less expensive. [Religious leader, Tonk]

However, participants also noted that while girls and boys below the legal minimum age at marriage are technically not allowed to get married at a mass marriage ceremony, parents find a way of circumventing this requirement and get their daughters married at such ceremonies regardless of their age. 
She was 14 years old. She did not want to get married, but I got her married at the community centre.... No, they do not perform the marriage of young girls. Normally, they allow girls over 18 years to get married. My daughter has a good height and is healthy. That is why they allowed her to get married at the mass ceremony. [Father of married girl, Tonk]

They do not allow a girl under 18 to get married. The workers there told me that my daughter was too young. I told them that I have many daughters; I persuaded them and got my daughter married. [Father of married girl, focus group discussion, Tonk]

\section{Investment schemes intended to} delay marriage

During interviews, government officials in the Department of Women and Child Development noted that the Balika Samridhi Yojana, a scheme supported by the central government intended to delay age at marriage and change family and community attitudes towards girls, recently had been introduced in the state. They also mentioned Raj Laxmi Yojana, another investment scheme sponsored by the state government that was stopped some years back.

In both study sites, only a few participants (10 out of 112 in-depth interviews/ key informant interviews/ focus group discussions conducted) reported that they had heard about schemes in which parents were paid money to delay their daughter's marriage till the age of 18 years. None of the participants were aware of anyone who benefited from such schemes.
Yes, they give Rs. 5,000-10,000 when a girl is 18 years old. They check the voter's list or the ration card for age verification and give them the money. [Father of married girl, focus group discussion, Tonk]

There was a fixed deposit scheme for girls; when a girl is 18 years old, she will get the money. No one in the village has benefited from it. [Teacher, Tonk]

...there is one scheme in which if the parents get their daughter married after she turns 18, they will be given Rs. 10,000. [Unmarried girl, Alwar]

\section{Educational and livelihoods projects}

Programmes that promote schooling and livelihood activities among adolescent girls have the potential of delaying their age at marriage. Several projects were identified by district officials in the Department of Education as promoting schooling for girls. These include scholarships for girls who excel in their studies (for example Gargi Puraskar), programmes to raise awareness about the importance of schooling in general and for girls in particular (for example, Shiksha Apke Dware, Kala Jatha) and schemes to facilitate the regular attendance of children in school, enable those who discontinued schooling to go back to school and to provide some level of literacy to those who have never attended or discontinued schooling (for example, Sarva Shiksha Abhiyan, Shala Purva Siksha, Kasturba Gandhi Balika Vidyalaya, Bridge courses or Transitional classes, Siksha Mitra).

As can be seen from the following quotes, respondents were of the view that the government has over the years been focusing considerable attention on 
education. However, while many respondents had heard of the Sarva Shiksha Abhiyan, there was virtually no awareness of other educational schemes. Moreover, some respondents were of the view that gains from the government's efforts to promote education have been negligible.

The government is currently paying a lot of attention to education. We have night classes run by the Sarva Shiksha Abhiyan everyday.

The District Primary Education Programme is also going on for small children. [Panchayat leader, Tonk]

We have a programme to promote education. We have a girls' education scheme. We give them books and lunch daily in the school to make them come to school. [Panchayat leader, Alwar]

Programmes to provide training and build the skills of young girls were identified. For example, district-level officials in the Department of Women and Child Development reported that the department is running the Kishori Shakti Yojana, previously known as the Adolescent Girls Scheme, incorporated within the existing Integrated Child Development Services (ICDS). Under this scheme, 11-18-year-old girls are provided training in vocational skills to empower them and enhance their self-esteem. Girls are given information to improve their ability to address nutrition and health issues.

However, none of the study participants mentioned these schemes. A few participants reported that girls were being given training in vocational skills through the anganwadi centre or the Nehru Yuvak Kendras.
We have a Nehru Yuvak Kendra here through which a stitching centre has been established. Training in stitching is given; when the girls learn how to stitch, they are provided their own sewing machines. [Teacher, Alwar]

In summary, the experiences of the communities with various government programmes related to early marriage are varied and fairly superficial. Most people had witnessed campaigns against early marriage and there is thus broad awareness of the legal age at marriage. Indeed, participants mentioned diverse sources of information on the topic - from anganwadis to mass media. There is also broad awareness that arranging marriages of children aged below the legal minimum age is an offence punishable by imprisonment. In contrast, most people had never heard of the government policy regarding registration of marriage, various schemes intended to delay age at marriage including mass marriage ceremonies and investment schemes, or schemes to promote livelihood activities among adolescent girls.

Data also show that laws, policies and programmes are implemented inconsistently. For example, the Child Marriage Restraint Act is not enforced; it is easy to disguise early marriages, people are loath to report on other community members and the police and others are easily convinced not to punish violators. Policies making marriage registration compulsory fail at an even earlier stage; few local government leaders are even aware of this.

Mass marriage ceremonies, which provide welcome relief for community members from exorbitant marriage costs, do not necessarily prevent early 
'She knew only when the garland was put around her neck': Findings from an exploratory study on early marriage in Rajasthan

marriages. According to participants, underage girls and boys are not necessarily excluded, though they should be. None of the participants are aware of anybody who benefited from any incentive schemes to encourage delayed age at marriage. While most people acknowledged that schemes to promote schooling for girls have increased over the years, their awareness of such schemes, except Sarva Shiksha Abhiyan, was negligible. 


\section{Delaying age at marriage: Recommendations for action from the communities}

There was a general consensus among the participants that early marriages should be prevented. Several ideas for policies and programmes to prevent early marriage were suggested by study participants as well as in the subsequent data interpretation workshops. These suggestions included community mobilisation through sustained campaigns, improving educational and vocational training opportunities for girls, providing financial incentives for parents, enforcing the law and addressing gender biases prevailing in the community. While most of the recommendations made by the communities are ideas the government has tried to foster, the communities' suggestions take these ideas to a greater level of intensity or include ways of fixing the lacunas in existing interventions. These recommendations are discussed in this chapter.

\section{Community mobilisation through campaigns}

Almost all the study participants as well as those who attended the data interpretation workshops were of the view that the practice of early marriage cannot be prevented unless the community is actively involved. Participants suggested that an effective strategy to mobilise the community to proactively take up the issue of early marriage would be to involve influential persons, such as religious and political leaders, who can help make the community understand the reasons why early marriage should be prevented. It was also suggested that awareness-raising campaigns should incorporate messages highlighting the adverse consequences of early marriage, and how it is a violation of the rights of the child. Others who could influence the community were teachers and educated persons in the villages.

Workshops should be organised with members of the panchayat, who are the anchor of the community; only if they are involved in raising awareness will change be effective. We have been writing slogans for years; if we want to effectively end this practice of early marriage, we must involve the panchayat. [Participant at the data interpretation workshop, Alwar]

Politicians and the sarpanch [village head] should take the initiative to stop child marriages in the village. They should organise street plays and protest rallies against child marriages, and should counsell the father and the elders of the family.

[Married girl, Tonk]

Several participants observed that while messages should be directed at all members of the community, campaigns to raise awareness about the adverse effects of early marriage should focus on community elders and parents of girls. Changing the 'nazaria' (mindset) of these gatekeepers was seen as vital. Some suggested that peer groups of parents could be formed that would provide a platform to share both positive and negative experiences and also to promote role models that could be emulated.

They [elders in the community] should be counselled as they are the ones who force the girl's parents to get her married at a young age. Counselling them would definitely have a very good impact on the practice of early marriage.

[Father of unmarried girl, Tonk] 
Parents should be convinced about it [ending early marriage]. Parents of the girls should be told about the disadvantages of early marriage.

[Youth leader, Tonk]

Participants also felt that it is important to raise awareness among parents of boys, as boys' parents also fuel the demand for young brides.

To address early marriage there is a need to address the parents of both young boys and young girls and to convince them not to marry their children before the legal age. [District Collector, Tonk] We focus on the parents of the girl, but not on the boy's parents who are also culprits.

[NGO representative, Alwar]

Participants also noted the need to raise awareness among young girls and boys about the adverse effects of early marriage. Some suggested that youth volunteers could be trained to raise awareness, as they have been successfully involved in other social awareness campaigns. Organising girls' groups to meet and advocate against child marriage was also thought to be a potentially effective intervention.

It is important to raise awareness among daughters as well. [NGO representative, Tonk]

There is also a need to focus on young boys and to convince them not to marry before 21 years. If boys agree to marry only when they are 21 , then young girls will not get proposals from them till they are of the legal age. This will automatically raise the age at marriage. [District Collector, Tonk]

In schools, children should be made aware that early marriage is an offence. A chapter should be introduced in school textbooks to raise awareness of the consequences of early marriage. [Participant at the data interpretation workshop, Alwar]

Many participants felt that campaigns to prevent early marriage should be ongoing, instead of the current practice of organising campaigns sporadically, for example, around Akha Teej (an auspicious day when numerous marriages, including child marriages, are conducted in the state).

We need to raise awareness throughout the year in the village community; it is important that the pradhan [village head] is also present at such sessions. [NGO representative, Tonk]

People should be told time and again about the adverse effects of early marriage. Then we can gradually stop early marriages. [Mother of married girl, Alwar]

They [parents] should be told repeatedly that getting married at an early age is bad.

[Married girl, Alwar]

It was agreed that the community should be mobilised not only to raise awareness about the adverse effects of early marriage - something that is already being done - but to take it a step further and to help parents resist community pressure that fosters the practice of early marriage. This includes the community taking on the responsibility of being vigilant and reporting cases of early marriages to enforcement authorities. Similarly, the community, particularly panchayat members, local government functionaries and priests, should be mobilised to boycott functions for marriages of under age girls and 
boys as attending such marriages only endorses this practice.

Often parents face the pressure of dowry and of finding a "suitable boy". The community usually exerts these pressures. Instead, the community should help parents realise that they are not helpless. There should be a consensus in the community that they should only marry a girl when she becomes an adult.

[Religious leader, Tonk]

If everyone does the same thing, for example, if 25 girls remain unmarried until they become mature, then no one would say that these girls are old enough to be married. Then they would not have any pressure to get their daughter married. [Father of unmarried girl, Tonk]

Thus, while participants and stakeholders put forward some predictable ideas about "raising awareness," they also clearly articulated that it was not enough. The mobilisation efforts that they describe imply far more than education campaigns, they call for fundamentally changing community norms around the practice through strategic engagement of influential leaders, through fostering active participation of the community in the elimination of early marriage and through generating a "critical mass" of innovators.

\section{Promoting education and livelihoods training for girls}

Participants recognised that the practice of early marriage would continue until concerned stakeholders make a concerted effort to promote girl's education.
They felt that educated girls could convince their parents to postpone their marriage or even refuse to get married at a young age. Likewise, if acceptable education opportunities were available, parents would allow their daughters to study and would delay their marriages.

If she is studying, she can tell her parents that she does not want to marry at a young age. Even her parents would think that it is all right if the girl is studying. [Religious leader, Tonk]

If they [parents] get some support from the government, parents would also think about their daughters' future and would allow them to study. They would not hesitate to educate them and would be happy to get them married at an older age. [Father of unmarried girl, Alwar]

It was felt that more schools (primary, middle and secondary) should be established in the area, and separate schools should be opened for girls. Issues such as the lack of teaching staff and the poor quality of teaching also need to be addressed as they affect school attendance. It was also suggested that communities should participate more actively in issues concerning education, for example, by pressing the local government authorities to improve the education infrastructure or by taking the initiative to set up schools themselves. Micro-planning at the field level could also be effective; for example, a small group of people could create awareness in the community of the importance of education and draw up a plan of action to make educational facilities available locally. School teachers and local leaders could be part of such groups. 
If the sarpanch and ward members convince the village people, the situation can be changed. They should make the people understand the merits of education. [Father of unmarried girl, Alwar] Separate schools for girls should be opened in the village; there should be female teachers for the girl students; the government should provide free education, textbooks and note-books. The community should work along with the government to bring these facilities to the village.

[Father of married girl, Alwar]

The school should be till class 10. If there is a school in the village, then the life of the girls would improve. [Mother of married girl, Tonk]

Participants also suggested that the provision of livelihoods training, either in school or outside the school, would help girls develop marketable skills and become more self-reliant. They felt that this could help delay age at marriage. Some participants observed that offering livelihoods training along with education would help keep girls in school as the content would help engage them and retain them even if they were less interested in the academic subjects. It was suggested that training centres should be located in the village and the training should be arranged at a time convenient for the girls.

\section{Addressing the economic issues driving early marriage}

Given the findings that poverty and the burden of marriage-related expenses are key factors underlying the persistence of early marriage, it is not surprising that participants suggested that parents of girls be provided with financial incentives to delay the marriage of their daughters. While this sounds like an idea that has been tried, findings from this study suggest that no existing government scheme to provide incentives has been more than spottily implemented - or perhaps implemented at all -in the study areas to date.

To stop early marriages, the government should give some incentives to the girls' parents. They should be given these incentives so that they are motivated and only begin marrying their daughters when they are 18 years or older. [Panchayat leader, Alwar]

If schemes where the government gives cash rewards to parents who marry their daughter after she is 18 years old are implemented in the village, parents would get their children married after they have attained the legal age. [Unmarried girl, Tonk]

Other recommendations to deal with the economic drivers of early marriage were made as well. For example, it was also suggested that community mass marriages, which are apparently effective in reducing marriage-related costs, could be organised, but with the explicit caveat of obtaining proof that the bride and groom are of legal age. A few participants suggested that efforts should be made to ban the payment of dowry as it is another major marriagerelated expense and one that is perceived to increase with girls' increasing age.

They should stop arranging marriages at home and do these at a sammelan [community mass marriage ceremony]. Both of them [the boy's and girl's families] should deposit money and get 
married without any dowry. [Mother of unmarried girl, Tonk]

Addressing the economic factors that underlie early marriage is vital and participants in the study and in the workshops made concrete suggestions to ameliorate them. While these ideas are not "new" per se (as discussed, the government has, on paper, schemes to provide financial incentives to delay marriage), these existing schemes have either not been implemented effectively or not been implemented at all in the study areas.

\section{Enforcement of the law}

Participants were of the view that the Child Marriage Restraint Act should be stringently enforced, and that the police should take action even on anonymous reports as an anonymous complainant would not have to fear reprisal.

Mothers and fathers would not stop this. But, if one or two of them get imprisoned, others will stop doing it. [Mother of married girl, Tonk]

The government should be strict; those who follow the rules should be rewarded and those who do not follow the rules must be punished or penalised. The police should be strict; they should give a punishment to those who practise early marriage.

[Father of married girl, Alwar]

It was also suggested that the registration of marriages should be made compulsory. Participants at the data interpretation workshops suggested that religious leaders should be involved in the process of registering marriages to ensure that only persons of legal age marry. It was also suggested that gram sevaks (village level workers) could be involved in the process of registering marriages.

The government should start registration of marriages. If marriages were registered, no one would be able to arrange the marriage of an underage child. Then, this [early marriage] would automatically stop. [Father of unmarried girl, focus group discussion, Tonk]

While participants felt that actual enforcement of existing laws would be important, at the same time, as some high-level government officials noted, it should be recognised that it may not always be possible to find a legal solution to the practice of early marriage, and that efforts would need to go beyond legal enforcement and address the factors underlying the persistence of early marriage.

\section{Addressing gender biases}

Interestingly, a few participants suggested that there is a need to address societal norms that view girls as a burden if the practice of early marriage is to be prevented. It was felt that gender discrimination in providing education should be stopped; and till practices that disadvantage and devalue girls are stopped, it will not be possible to change such traditional practices.

There should be no discrimination between boys and girls; girls should also be given a proper education. [Mother of unmarried girl, Tonk] To start with, we should end the discrimination between a boy and a girl from the minds of parents 
and society. Only then can we achieve some success in our efforts to stop early marriages. [Father of unmarried girl, Alwar]

As long as parents don't change their attitude, girls will not be educated..., there will be no change in their daughter's future, and daughters will not be able to progress. The need for parents to change their attitude is important. [Participant at the data interpretation workshop, Tonk]

[I] t is equally important to change the mindset regarding girls that they are parayadhan [someone else's property], that they are rehene wale nahin hai [do not 'belong' in their natal family] or that they should only be involved in housework and not educated. [NGO representative, Tonk]

To sum up, participants in the study and workshop clearly recognised the need for preventing the practice of early marriage and made a number of recommendations for doing so. Because existing efforts have either not reached these communities or have been superficial in their approach, participants proposed interventions to delay age at marriage that would go beyond information campaigns, and beyond the level of policy formulation to address fundamentally the social norms and economic factors that underlie early marriage. Mobilising the community to resist early marriage, promoting girls education, providing livelihoods training for girls, offering financial incentives to parents to delay the marriage of their daughters, eliminating dowry, enforcing existing laws and levying penalties for violators and fostering gender equity, were the top suggestions for action. These recognise the need that a tougher, multifaceted approach is needed to make inroads against this entrenched practice. 


\section{Summary and conclusions: Moving beyond exhortations to clear incentives, sanctions, and community contracts}

This chapter summarises the key findings of the study and makes recommendations for eliminating the practice of early marriage.

\section{Summary}

The findings from this study provide insight into the underlying drivers of early marriage in Rajasthan and the possibility of changing this traditional practice. Girls, whether married or unmarried, had a clear desire to marry after the age of 18 . In both sites, they articulated what they would have to give up with marriage - their education, childhood, health and opportunities to explore other interests; and what awaited them in their marital home, including parenthood, less freedom of movement, housework and other responsibilities. Some parents also noted these disadvantages of early marriage, suggesting that beliefs surrounding the practice of early marriage may be changing in the study areas. At the same time, the findings that parents continued to control the timing of marriage, disregard their daughters' preferences in the marriage arrangement process and get their daughters married at ages earlier than desired by the girls, clearly highlight that many are yet to act on these new beliefs.

Parents, girls and key informants cited a range of interrelated factors for the persistence of early marriage despite the fairly wide acknowledgement of its disadvantages, and despite girls' clear preferences for delaying marriage. The primary reason was financial, particularly the high cost of marriage-related expenses, including payment of dowry, and parents' efforts to avoid such expenses by conducting joint ceremonies for all daughters, even if the youngest is still a child. Another key reason was real or anticipated social pressure from other community members, ranging from interfering comments to disparaging remarks about the unmarried girl. Also mentioned were gender biases that limit girls' educational opportunities; gender norms that view girls' maturing bodies as a liability or danger and require situating her in the perceived "safety" of marriage to protect her, and her family's honour; and fears that delaying marriage would reduce the likelihood of finding a suitable groom for the girl.

The experiences of the communities with various government programmes related to early marriage are fairly superficial. Following government efforts to delay age at marriage, including the organisation of media campaigns, disseminating messages through anganwadi workers and other health workers and issuing orders to directly ban early marriage, many respondents were well aware of the fact that marriage before 18 is illegal. In contrast, most people had never heard of the government policy regarding registration of marriage, various programmes intended to delay age at marriage including mass marriage ceremonies and investment schemes or initiatives to promote livelihood activities among adolescent girls.

Data also show that laws, policies and programmes are weakly enforced or rarely or inconsistently implemented in these districts. For example, only a few participants knew of schemes 
providing positive incentives to delay age at marriage, for example the Raj Laxmi Yojana and the recently introduced Balika Samridhi Yojana. No one was aware of anybody who had actually benefited from such schemes. Respondents also astutely observed that it is easy to get around the laws and legal sanctions. For example, even large community weddings organised to reduce marriage-related costs, which require the bride and groom to be 18 and 21 years respectively, are open to manipulation, and girls under 18 are allowed to get married at these ceremonies following the payment of a small bribe or other consideration. Moreover, the community itself appears unconcerned or hesitant to take on the issue; few would register a complaint if a neighbour married their young daughter. In fact, the fear of social ostracism, as well as their own preference for early marriage, makes it unlikely that neighbours or others would disclose an illegal ceremony to the authorities.

The findings show that study participants are of the view that the practice of early marriage should be prevented and they made several suggestions. While their recommendations are not, at first glance, 'new,' they include ways of improving the interventions that are already being tried or that have been implemented patchily to date. Their suggestions included measures that would go beyond information campaigns and the level of policy formulation to address fundamentally the social norms and economic factors driving early marriage in these districts. Mobilising the community to resist early marriage, promoting girls education, providing livelihoods training for girls, offering financial incentives to parents to delay the marriage of their daughters, eliminating dowry, enforcing existing laws and levying penalties for violators and fostering gender equity, were the top suggestions for action. Suggestions for next steps, reflecting discussions at the workshops as well as findings from the data, are discussed below.

\section{Increasing the pressure:} Recommendations for an intensified, multi-pronged approach

\section{Beyond exhortation: Critical analysis of gender and society}

While information campaigns to inform people of the benefits of delaying marriage can increase awareness, they are unlikely to be sufficient to change traditional practices. The underlying socio-economic factors and gender norms that perpetuate the practice will also need to be addressed. This will require more active engagement with the community, for example, working with community members, including political and religious leaders and parents, to critically examine the practices surrounding marriage, how they increase families' economic insecurity, deny girls their right to education and time to mature, deprive both girls and boys of their right to consent in marriage and effectively treat females as property. These efforts will have to move beyond mere didactic exhortations to help people examine and understand the gender and social norms and dynamics that perpetuate them. Such critical examination of social context can be done in participatory group discussions, facilitated in classrooms and at community level. 


\section{Community contracts: Fostering new norms and new practices}

One possible strategy that could result from such processes is to encourage public statements and pledges not to marry one's daughter before the stipulated legal age. Such efforts have been undertaken around other harmful and entrenched practices with good results (Diop et al, 2004). Initial groups of parents making such public and celebrated pledges would generate a critical mass of community members acting as innovators. As study participants noted, if enough people commit to change and delay the marriage of their daughters, others will follow. Religious leaders and other respected individuals in the community could be enlisted to help in this process of evolving new norms and new practices.

\section{Meaningful consent: Respecting girls' desires and rights}

Another possible strategy in this vein is to foster the idea of consent to marriage - a notion codified in international agreements as well as in Indian policies. That is, to encourage parents to solicit and respect their daughter's views on the timing of marriage and choice of husband. This would entail working with both parents and their daughters to build awareness of human rights, and to critically examine the social norms that do not allow girls or boys to have a say in the timing or choice of their spouse. Again, people and institutions respected in the community as leaders can be trained and enlisted to speak out on this topic.

\section{Economic incentives: Rewarding later age at marriage}

Respondents frequently cited the economic factors that drive early marriage in these communities. The practice of dowry, the exorbitant expenditures on weddings and the perception that costs will only increase as a girl gets older, are an economic stress on a household and are a key factor underlying parents' decision to marry their daughters at young ages. In addition to helping community members critically analyse these deleterious practices in efforts such as those described above - perhaps including dowry among the pledge activities - financial incentives are recommended. Community members and stakeholders felt that incentive schemes could lessen the economic pressure families feel to marry off their daughters at an early age. Such schemes exist on paper but now need to be implemented in these communities.

\section{Penalties: Implementing the law}

Similarly, while early marriage is technically a punishable offence, it is rarely penalised in practice. Study respondents and stakeholders alike felt that more rigorous enforcement of existing laws and policies could help to discourage early marriage. Allowing anonymous reporting, working with the police and others to make clear that this is not a minor violation and that it is not acceptable to look the other way and making guidelines for penalties clear and transparent are possible steps. For such changes, bold and committed leadership is vital. 
Encouraging alternatives to early marriage: Education and livelihoods

Efforts to delay marriage would also require providing girls meaningful and viable alternatives to marriage. Advising families to send their daughters to school when schools are too far, the classroom is hostile to girls or education is of poor quality, will not work. Working with the education sector to make schooling for girls more accessible, and to make classrooms more gender-sensitive and responsive to the needs of young girls and the concerns of their parents are important recommendations. Likewise, efforts to provide livelihoods training, within or outside the educational system, are called for.
The findings from this study suggest that a collective level effort to eliminate early marriage may be well received in these communities in Rajasthan. Participants and stakeholders alike explicitly or implicitly recommended a broad, community-based approach to address early marriage. While previous efforts to delay marriage have been insufficient or haven't been implemented, an awareness - and perhaps a nascent openness to change does exist in these communities. Fostering "valuing" institutions such as education and livelihoods programmes for girls while at the same time discouraging "de-valuing" ones such as early marriage and dowry, sends vital, reinforcing messages regarding girls' and women's rights, opportunities, potential and dreams. 


\section{References}

Bruce, J. and S. Clark. 2004. The implications of early marriage for HIV/AIDS policy, Policy Brief, New York: Population Council

Diop, N., M. Faye, A. Moreau et al. 2004. The TOSTAN Program: Evaluation of a Community Based Education Program in Senegal. New York: Population Council

Haberland, N., E. Chong and H. Bracken. 2004. A world apart: The disadvantage and social isolation of married adolescent girls, Policy Brief, New York: Population Council

Miller, S. and F. Lester. 2003. Improving the health and well-being of married young first time mothers, paper presented at the Technical Consultation on Married Adolescents, organised by World Health Organisation, 912 December, Geneva

National Research Council (NRC) and Institute of Medicine (IOM). 2005. Growing Up Global: The Changing Transitions to Adulthood in Developing Countries, ed. C. Lloyd. Washington, D.C: National Academies Press

Registrar General of India. 2001. Census of India, Provisional Population Totals, Series I, Paper I. 2001. New Delhi: Office of Registrar General

United Nations. 1989. Convention on the Rights of the Child, General Assembly Resolution 44/25, New York: UN 


\section{Appendix}

Table 1:

Proportion ever-married among 15-19-year-olds: Major states and all India

\begin{tabular}{|c|c|c|}
\hline \multirow[t]{2}{*}{ States and India } & \multicolumn{2}{|c|}{$\%$ of ever-married $15-19$-year-olds } \\
\hline & Females & Males \\
\hline Rajasthan & 40.8 & 14.7 \\
\hline Bihar & 39.6 & 8.6 \\
\hline Madhya Pradesh & 34.1 & 9.6 \\
\hline Jharkhand & 32.9 & 6.4 \\
\hline Andhra Pradesh & 32.3 & 3.1 \\
\hline West Bengal & 29.4 & 3.2 \\
\hline Uttar Pradesh & 27.4 & 7.9 \\
\hline India & 24.9 & 5.3 \\
\hline Haryana & 24.8 & 6.3 \\
\hline Chattisgarh & 22.0 & 5.0 \\
\hline Tripura & 20.7 & 2.3 \\
\hline Assam & 20.6 & 2.6 \\
\hline Karnataka & 20.4 & 2.2 \\
\hline Gujarat & 18.0 & 5.0 \\
\hline Maharashtra & 17.7 & 2.1 \\
\hline Arunachal Pradesh & 17.6 & 3.9 \\
\hline Sikkim & 16.6 & 3.9 \\
\hline Tamil Nadu & 15.7 & 2.1 \\
\hline Meghalaya & 15.6 & 2.6 \\
\hline Orissa & 14.1 & 2.0 \\
\hline Uttaranchal & 13.3 & 2.2 \\
\hline Kerala & 13.3 & 0.9 \\
\hline Delhi & 12.6 & 3.3 \\
\hline Jammu \& Kashmir & 11.5 & 3.6 \\
\hline Punjab & 11.0 & 3.8 \\
\hline Mizoram & 10.9 & 2.3 \\
\hline Himachal Pradesh & 9.3 & 2.0 \\
\hline Manipur & 8.8 & 2.0 \\
\hline Nagaland & 8.4 & 1.9 \\
\hline Goa & 7.8 & 1.5 \\
\hline
\end{tabular}

Source: RGI, 2001. 
Table 2:

Proportion ever-married among 15-19-year-olds: Districts and Rajasthan

\begin{tabular}{|c|c|c|}
\hline \multirow[b]{2}{*}{ District } & \multicolumn{2}{|c|}{$\%$ of ever-married $15-19$-year-olds } \\
\hline & Females & Males \\
\hline Bhilwara & 61.9 & 34.1 \\
\hline Tonk & 59.2 & 30.9 \\
\hline Rajsamand & 56.4 & 24.2 \\
\hline Bundi & 55.9 & 24.7 \\
\hline Chittaurgarh & 55.7 & 27.5 \\
\hline Jhalawar & 54.2 & 22.0 \\
\hline Sawai Madhopur & 50.4 & 20.5 \\
\hline Nagaur & 48.6 & 18.3 \\
\hline Churu & 48.2 & 14.1 \\
\hline Dausa & 46.8 & 18.6 \\
\hline Karauli & 46.7 & 17.5 \\
\hline Ajmer & 44.1 & 22.2 \\
\hline Alwar & 42.3 & 16.7 \\
\hline Bikaner & 42.3 & 13.0 \\
\hline Baran & 41.7 & 12.3 \\
\hline Sikar & 40.6 & 12.4 \\
\hline Rajasthan & 40.8 & 14.7 \\
\hline Dhaulpur & 40.1 & 10.5 \\
\hline Jodhpur & 37.9 & 12.7 \\
\hline Jaipur & 37.7 & 14.3 \\
\hline Pali & 37.0 & 12.9 \\
\hline Jaisalmer & 36.5 & 5.4 \\
\hline Bharatpur & 35.6 & 11.2 \\
\hline Udaipur & 35.3 & 10.9 \\
\hline Hanumangarh & 34.3 & 9.7 \\
\hline Barmer & 33.3 & 7.9 \\
\hline Jalore & 33.2 & 10.2 \\
\hline Jhunjhunu & 32.8 & 8.0 \\
\hline Banswara & 31.4 & 11.9 \\
\hline Kota & 30.7 & 7.9 \\
\hline Dungarpur & 28.6 & 8.1 \\
\hline Ganganagar & 25.2 & 6.4 \\
\hline Sirohi & 24.3 & 4.1 \\
\hline
\end{tabular}

Source: RGI, 2001. 


\section{Authors}

K.G. Santhya is Senior Programme Officer, Population Council, New Delhi

Nicole Haberland is Programme Associate, Population Council, New York

Ajay Kumar Singh is Assistant Programme Officer, Population Council, New Delhi 
